\title{
EFFECT OF HUMIC ACID AND BIO-MOS SUPPLEMENTATION ON EGG PRODUCTION AND QUALITY PARAMETERS IN LOCAL HENS. \\ Abo-Egla, El-Samra H. ${ }^{*}$; F. S. A. Ismail ${ }^{\star}$; F. A. Abd El-Ghany ${ }^{\star *}$ and M. H. Assar** \\ * Dept. of Poultry Production, Fac. Agric, Mans. Univ. \\ ${ }^{\star *}$ Animal Production Res. Inst., Agric. Res. Center. Dokki, Giza.
}

\begin{abstract}
This study was designed to investigate the inclusion effect of humic acid (HA) and mannanoligosaccharide (Bio-Mos) into laying hen diets on egg production and egg quality. Gimmizah layers $(n=210) 30 \mathrm{wk}$ of age were fed a control diet , $0.1,0.2$ and $0.3 \%$ humic acid and $0.1,0.2$ and $0.3 \%$ Bio-Mos for 90 days. Feed consumption was measured weekly and feed conversion was calculated.. Mortality was recorded daily. The number of eggs and egg weight were recorded daily throughout the experimental period. Also a sample of 30 eggs from each group was collected randomly to determine egg quality every 30 days. The results were summarized as follow: egg weight and egg production for hens supplemented with humic acid and Bio-Mos were significantly increased compared with the control group. Dietary treatments had insignificant effect on feed intake. No significant effect of humic acid or Bio-Mos had insignificantly effect on egg shape index, albumin (\%), Haugh unit and egg yolk index. Whereas, egg shell thickness was significantly $(p<0.05)$ increased compared with the control group. In conclusion, supplementation of humic acid and Bio-Mos during laying period significantly increased egg production, egg weight and improved egg shell quality.
\end{abstract}

\section{INTRODUCTION}

Using alternatives to antibiotic growth promotants in commercial chickens have become important mainly because of apprehension about the possible development of resistant bacteria. At the same time, continuous use of antibiotic growth promotants in breeders may have one important ramification that could affect the poultry industry, reduction in the efficacy of antibiotics when used in progeny that are hatched to the same parents (Shashidara and Devegowda ,2003). Also, antibiotic growth promotants resulted in the occurrence of resistant microorganisms which become one of the major problems in human medicine.

Humic acid (HA) is resulting from decomposition of organic matter, particularly plants, and it is natural components of drinking water, soil and lignite, moreover, it has been used as an antidiarrheal ,analgesic , immunostimulatory and antimicrobial agent in veterinary practices in Europe (EMEA, 1999). Many experimental studies have shown HA to be nontoxic and nonteratogenic (EMEA, 1999 and Yasar et al., 2002) .

Humates are the salts of humic acid in which the exchange site is $\mathrm{Ca}+$, $\mathrm{Na}+\mathrm{AL}+$ and $\mathrm{Fe}+2$ rather than hydrogen ( Humin Tech, 2004). Previous studies with respect to humates have focused mainly on the growth of germinal tissue in seed. The idea of using humates as feed additives in 
Abo-Egla, El-Samra H. et al.

animal nutrition is new. Humates have been used for their anti-inflammatory, antioedematous, anti-bacterial and antiviral effects on animals (Joone et al., 2003). The concept of using humates as an alternative feed additive in animal nutrition has gained increasing importance, particularly after the ban on antibiotic use in feeds as growth promoters.

Bio-Mos is derived from the outer cell wall of yeast. Mannose, the main component of Bio-Mos, is a unique sugar because many enteric bacteria have receptors that bind to it (Griggs and Jacob, 2005). The Bio-Mos supplementation is considered become it is not only shifts gastrointestinal microflora balance toward beneficial organisms (Spring at al., 2000; Fairchild et al., 2001) , but also resulted in significant improvement in antibody responses in broiler and layers (Cotter et al., 2000; Cotter et al., 2002 and Raju and Devegowda, 2002).

The objectives of this study were to investigate the effects of supplementation of humic acid and Bio-Mos on egg production and egg quality parameters of local hens.

\section{MATERIALS AND METHODS}

\section{Birds, Diet and Management:}

A total of 210 hens from Gimmizah strain at 30 weeks of age and with uniform BW, were placed in floor pens. They were then assigned randomly to be fed 1 of 7 isocaloric and isointrogenous experimental diets: a basal diet containing neither humic acid nor Bio-Mos and diets containing either humic acid $(0.1,0.2$ and $0.3 \%)$ or Bio-Mos $(0.1,0.2$ and $0.3 \%)$. Each treatment was replicated in 3 pens with 10 hens each. Each kilogram of humic acid contained $85 \%$ polymeric polyhydroxy acid, 10\% phosphorus, $2 \%$ magnesium, $2 \%$ sulpher and $1 \%$ trace minerals (iron, zinc and manganese). The Bio-Mos preparation used in these studies was the commercial product Bio-Mos $\AA$ produced by Alltech, Nichola Siville, Kentucky USA.the composition of the basal experimental diet was presented in table 1. Water was available all the times and lighting program of 16 hours a day was applied.

\section{Criteria of response:}

Individual body weights were recorded at the beginning and at the end of the study to calculate body weight changes. Feed consumption was measured weekly and feed conversion ratio was calculated. Mortality was recorded daily. The number of eggs and egg weight were recorded daily through the experimental period (90 days). An additional sample of 10 eggs was randomly collected from each experimental group every 30 days to assess egg quality parameters as egg shape index \% (Carter, 1968) and yolk index \% (Well 1968). Haugh units, as an indicator for albumen quality was calculated using the $\mathrm{HU}$ formula (Eisen et al., 1962). Shell thickness was determined at three locations on the egg (air cell, equator and sharp end) by using a micrometer. 


\section{Statistical analysis:}

Analysis of variance was computed using the general linear model (GLM) procedure of statistical analysis system according to SPSS (1999). Significant differences among means were evaluated using Duncan's multiple range test (Duncan, 1955).

\section{RESULTS AND DISCUSSION}

\section{Body weight change and mortality rate:}

Results in Table 2 indicated that humic acid and Bio-Mos supplementation had insignificant effect on body weight change.

Mortality rate for hens fed the control diet was not different from that for hens fed humic acid and Bio-Mos diets. The mortality rate was also not different among hens fed humic acid and Bio-Mos diets. There was also no effect of increasing the level of supplemental humic acid on mortality (Table 2). Autopsy findings revealed that deaths were related to noninfectious causes. Little is known about the mechanism by which humic acid supplementation enhances the life span and improves production efficiency. However, available data consistently suggest that humic acid supplementation of $\mathrm{Na}$ humate in rats exposed to lethal doses of radioactivity increased the life span. In similar studies, it was shown that after high doses, supplemental humate alleviated toxicity of $\mathrm{Cr}$ in fish (Stockhouse and Benson, 1989) and $\mathrm{Cd}$ in chickens (Herzig et al., 1994) by reducing deposition of toxic metals in organs. Supplementation with Bio-Mos has also been shown to enhance survival by altering gastrointestinal flora (Patterson and Burkholder, 2003) to suppress growth of pathogenic bacteria (Cotter et al., 2002) and by enhancing immune potency (Cotter et al., 2000).

\section{Feed intake and egg production:}

The experimental diets had no effects on feed intake (Table 2). Similar results was obtained by yoruk et al., (2004) who found that humate with concentration of 0.1 and $0.2 \%$ had no significant effect on feed intake in late stage of laying. Also, in broiler chickens, Kocabagli et al., (2002) indicated that no significant effect on feed consumption was observed when birds group fed diet with humate. While, Kucukersan et al., (2005) showed that the average daily feed consumption of hen fed diets with humic acid was significantly $(p \leq 0.05)$ decreased compared with the control group. The mechanism by which humic acid effects poultry performance is largely unknown, whereas it is well established that Bio-Mos alter gastrointestinal PH and flora to favor on increased activity on intestinal enzymes and digestibility of nutrients (Shin et al., 2005). In similar studies involving broilers, Idespite a lack of feed intake data, it was reported that supplementation of humate (Kocabagli et al., 2002) did not alter feed conversion efficiency on day 21, but improved it on day 42. It appears that supplementation of humate and BioMos do not improve growth by affecting feed intake per se, suggesting that improvement in weight gain and reduction in feed conversion efficiency by supplemental humic acid and Bio-Mos could be related to their promoting effects on metabolic processes of digestion and utilization of nutrients (Yeo 
and Kim, 1997). Also, Table 2 showed that either of the dietary supplementation level of humic acid and Bio-Mos had a significant effect on egg weight and egg production percentage during the experimental period (12 weeks). Moreover, humic acid at $0.1 \%-0.2 \%$ and Bio-Mos at $0.2 \%-$ $0.3 \%$ caused a significant $(p<0.05)$ increase in egg weight and egg production percentage compared with the control group. These results are consistent with those reported by Kucukersan et al., (2005) who showed that the dietary humic acid at doses of 30 and $60 \mathrm{~g} / \mathrm{ton}$ feed can be used to improve egg weight and egg production.

Yoruk et al., (2004) found that supplementation of humate in layer diets at 0.1 and $0.2 \%$ for 75 days during the late laying period caused egg production increase compared to control group. On the other hand, Wang et al., (2007) indicated that the dietary humic substances at 5 or $10 \%$.decreased egg production but egg weight was improved. The addition of Bio-Mos with levels $(0.2-0.3 \%)$ improved egg weight and egg production. These results agree with Guerrero, (1995); Berry and Lui, (2000) and Stanley et al., (2000) reported considerable improvement in egg production and egg weight in the Bio-Mos fed birds. Shermer et al., (1998) who showed that the humic acid stabilizes the intestinal microflora and thus ensures an improved utilization of nutrients in animal feed. This leads to an increase in egg production and egg weight of laying hens. Talay et al., (2004) and Zhigang et al., (2004), found that Bio-Mos were significantly resulted in heavier body weight than unsupplemented diet (control diet). In the present study the increase in egg production and egg weight may be attributed to adsorption of toxin and pathogenic bacteria (Dawson, 2002), improved protein digestibility (Bonomi et al., 1978)

There was no difference in feed conversion efficiency of hens fed humic acid and Bio-Mos diets. However, there were slightly improvement in feed conversion efficiency for hens fed humic acid at level $(0.1$ and $0.2 \%)$ and Bio-Mos at levels $(0.2-0.3 \%)$ compared with hens fed the control diet (Table 2). These results are in agreement with results of studies involving broilers on supplementation of humate (Zhorina and Stepchenko, 1991; Kocabagli et al., 2002). Similar results of insignificant FC improvement were found in laying hens and Japanese quail at the same level of Bio-Mos supplementation were reported by Chukwu and Stanley (1997) and Ghosh et al., (2007).

\section{Egg quality:}

It was observed that there were no significant differences among treatments with respect to egg shape, albumen percentage, Haugh unit and yolk index (Table3). These traits were not affected by addition of humic acid or Bio-Mos to layer hen diets during the experimental period. The obtained results approach with those found by Yoruk et al., (2004); Kucukersan et al., (2005) and Wang et al., (2007). Egg shell thickness significantly $(p \leq 0.05)$ increased for hens fed either levels of humic acid or Bio-Mos compared with control with control group (Table 3). The increases in egg shell thickness were more pronounced when hens fed diet with high level of humic acid. These results approach with those reported by wang et al., (2007) who indicated that the egg shell breaking strength as indicator of shell thickness was increased for hen fed diets with humic substances compared with the 
control group. An earlier report by Chen and Balnave (2001) suggested that Carbonic anhydrase played an important role in egg shell formation, and showed optimal activity in slightly alkaline medium. We concluded in our study that humic acid might have improved egg shell calcification by increasing blood $\mathrm{Na}$ and $\mathrm{K}$ levels, or causing other Cation-anion changes. Although not well known yet, these types of metabolic events in the body may be one reason to the positive effect on egg shell quality.

Regarding of Bio-Mos supplementation resulted in significant increase in shell thickness (Table 3). Similarly, Berry and Lui (2000) and Shashidhara and Devegowda (2003) reported that the Bio-Mos improved egg shell quality traits in older breeder females, may be due to improvement in calcium availability. The obtained results indicated that humic acid and Bio-Mos has improved egg production, feed conversion, and egg shell quality. The positive effects of humic acid, possibly related to improved nutrient utilization through various metabolic activities in the body are yet to be further investigated.

Also different investigators showed that Bio-Mos maintain gut health by adsorption of pathogenic bacteria containing different bacterial strains and remove the pathogenic bacteria from gut (Oyofo et al., 1989 and Spring et al., 2000) and increase villus height, uniformity and integrity also, increase in Crypt depth is attributed to greater expenditure of energy to develop the absorptive surface (Dawson and Tricarico, 2002; Loddi et al., 2002; oliveira et al., 2006 and Ghosh et al., 2007).

Table (1): Composition and calculated analysis of the basal diet fed to experimental birds.

\begin{tabular}{|l|c|}
\hline Ingredients & $\%$ \\
\hline Yellow corn & 64.00 \\
Soybean meal (44\%) & 24.78 \\
Limestone & 7.91 \\
Di-calcium phosphate & 1.61 \\
Wheat bran & 1.00 \\
Salt (Nacl) & 0.30 \\
Vit.\& Min. Mixture* & 0.30 \\
DL.Methionine & 0.10 \\
\hline Total & 100 \\
\hline Calculated analysis & \\
\hline Metabolizable energy (kcal/kg) & 1713.00 \\
Crude Protein, \% & 16.03 \\
Crude fiber, \% & 3.39 \\
Crude fat, \% & 2.84 \\
Calcium, \% & 3.34 \\
Available phosphate, \% & 0.42 \\
Lysine, \% & 0.89 \\
Methionine, \% & 0.39 \\
Met+Cystine, \% & 0.66 \\
\hline
\end{tabular}

${ }^{\star}$ Supplied per kg of diet: vit.A, 10000 IU; $D_{3}, 2000$ IU; Vit.E, 10mg; Vit.K $K_{3}, 1 \mathrm{mg} ;$ vit. $B_{1}, 1 \mathrm{mg}$ vit. $B_{2}, 5 \mathrm{mg}$; vit. $B_{6}, 1.5 \mathrm{mg}$; vit. $B_{12}, 10 \mathrm{mcg}$; Niacin, $30 \mathrm{mg}$; Pantothenic acid, $10 \mathrm{mg}$; Folic

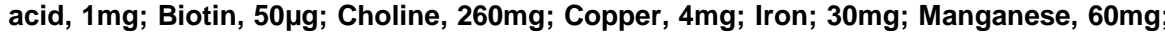
Zinc, $50 \mathrm{mg}$; lodine, $1.3 \mathrm{mg}$; Selenium, $0.1 \mathrm{mg}$; Cobalt, $0.1 \mathrm{mg}$. 
Abo-Egla, El-Samra H. et al.

Table (2): The effect of supplementation of humic acid and Bio-Mos on performance and production parameters of hen.

\begin{tabular}{|c|c|c|c|c|c|c|c|c|c|}
\hline \multirow[b]{2}{*}{ Parameters } & \multirow{2}{*}{$\begin{array}{c}\text { contro } \\
0\end{array}$} & \multicolumn{3}{|c|}{ Humic Acid (\%) } & \multicolumn{3}{|c|}{ Bio-Mos (\%) } & \multirow[b]{2}{*}{ SEM } & \multirow[b]{2}{*}{ Sig. } \\
\hline & & 0.1 & 0.2 & 0.3 & 0.1 & 0.2 & 0.3 & & \\
\hline Initial body weight & 1503 & 1498 & 1505 & 1501 & 1515 & 1503 & 1498 & \pm 15.17 & N.S \\
\hline & & 1726 & 1778 & 30 & 750 & 1 & 1773 & \pm 29.19 & N.S \\
\hline Bod & 12 & 13.22 & 15.36 & 13.19 & 13.41 & 13.60 & 15.48 & 1.25 & V.S \\
\hline & $2 / 30$ & $1 / 30$ & - & $2 / 30$ & $1 / 30$ & - & $1 / 30$ & + & IS \\
\hline Aorta & 6.66 & 3.33 & - & 6.66 & 3.33 & - & 3.33 & & \\
\hline ce $(g / h / d)$ & 100.66 & 100.81 & 100.97 & 101.14 & 102.08 & 100.53 & 102.28 & \pm 0.35 & N.S \\
\hline Egg & $48.25^{\mathrm{C}}$ & $49.29^{b}$ & $49.80^{a}$ & $49.24^{\mathrm{b}}$ & $49.21^{b}$ & $49.58^{\mathrm{at}}$ & $49.87^{\mathrm{a}}$ & \pm 0.29 & \\
\hline Egg F & $49.40^{c}$ & $50.12^{b}$ & $52.34^{a}$ & $49.21^{\mathrm{C}}$ & $50.12^{b}$ & $51.82^{\text {at }}$ & $52.62^{2}$ & \pm 0.85 & \\
\hline Eeed conversion ra & 4.13 & 4.08 & 3.89 & 4.19 & 4.14 & 9 & 3.92 & \pm 0.60 & 0.0 \\
\hline
\end{tabular}

Table (3): The effects of supplementation of humic acid and Bio-Mos on egg quality parameters of hens.

\begin{tabular}{|l|c|c|c|c|c|c|c|c|c|}
\hline \multirow{3}{*}{ Parameters } & Control & \multicolumn{3}{|c|}{ Humic Acid (\%) } & \multicolumn{3}{|c|}{ Bio-Mos (\%) } & \multirow{2}{*}{ SEM } & Sig. \\
\cline { 2 - 10 }$n$ & $\mathbf{0}$ & $\mathbf{0 . 1}$ & $\mathbf{0 . 2}$ & $\mathbf{0 . 3}$ & $\mathbf{0 . 1}$ & $\mathbf{0 . 2}$ & $\mathbf{0 3}$ & SEM \\
\hline Yolk (\%) & 32.45 & 32.27 & 32.28 & 31.96 & 32.52 & 32.02 & 32.11 & \pm 0.58 & N.S \\
\hline White (\%) & 56.59 & 56.93 & 56.44 & 56.89 & 56.45 & 56.99 & 56.61 & \pm 0.86 & N.S \\
\hline Shell (\%) & 10.95 & 10.78 & 11.27 & 11.14 & 11.02 & 10.98 & 11.27 & \pm 0.70 & N.S \\
\hline Yolk index (\%) & 45.49 & 45.22 & 46.89 & 45.25 & 45.87 & 46.76 & 46.43 & \pm 0.48 & N.S \\
\hline Haugh unit & 88.34 & 88.50 & 90.60 & 88.46 & 89.0 & 90.52 & 89.36 & \pm 1.25 & N.S \\
\hline Shell thickness $(\mathrm{mm})$ & $0.370 \mathrm{c}$ & $0.380 \mathrm{c}$ & $0.400 \mathrm{ab}$ & $0.410 \mathrm{a}$ & $0.378 \mathrm{c}$ & $0.396 \mathrm{ab}$ & $0.390 \mathrm{ab}$ & \pm 0.02 & $*$ \\
\hline Egg shape index & 76.86 & 76.81 & 77.32 & 76.96 & 77.01 & 77.21 & 76.95 & \pm 1.36 & $\mathrm{~N} . \mathrm{S}$ \\
\hline
\end{tabular}

\section{REFERENCES}

Berry, W. D. and Lui, P. (2000). Egg production, egg shell quality and bone parameters in broiler breeder hens receiving Bio-Mos and egg shell. Poult. Sci. 79(Suppl.1): 124(Abst.).

Bonomi A, Vassia G. (1978). Observations and remarks on the use of Saccharomyces cerevisiae and Kluyveromyces fragilis, in the form of living yeast, on the production and quant-qualitative characteristics of broilers. Arch. Vet. Ital. 29(Suppl.): 3-15.

Carter, T.C. (1968). The hen egg. A mathematical model with three parameters .Br. Poult.Sci. 9: 165-171.

Chen, J.; and Balnave, D. (2001). The influence of drinking water containing sodium chloride on performance and eggshell quality of a modern coloured layer strain. Poult. Sci., 80: 91-94.

Chukwu, H.I. and Stanley, V.G. (1997). Dietary Saccharamyces Cervisiae and mannanoligosaccharide reduced the deletrious effect of heat stress on white lehorn laying hens . association of Research Directors Eleventh Biennial Research ymposium October 1-4, 1997.

Cotter, P.F.; Malzone, A.; Paluch, B.; Lilburn , M. S.; and sefton, A.E. (2000). Modulation of humoral immunity in commercial laying hens by a dietary prebiotic. Poult. Sci., 79(Suppl.1): 38(Abst).

Cotter, P.F.; sefton, A.E.; and Lilburn , M. S. (2002). Manipulating the immune system of layers and breeders: Novel applications for mannanoligosaccharides. PP. 21-28 in Nutritional Biotechnology in the feed and food Industries. 
Dawson, K.A. and Tricarico, J. (2002). The evaluation of yeast cultures- 20 years of research. Navigating from Niche Markets to Mainstream Proceeding from Alltech's $16^{\text {th }}$ Annual European, Middle Eastern and African Lecture Tour.

Duncan, D.B. (1955). Multiple ranges and multiple F Test. Biometrics, 11: 142.

Eisen, E.J.; Bohren , B.B.; and mckeen, H.E.(1962). The haugh unit as a measured of egg albumen quality. Poult.Sci., 1461-1468.

EMEA. (1999). Humic acids and their sodium salts, summary report. Committee for veterinary Medicinal Products. Eur. Agency Eval. Med. Prod. http:/www.emea.eu.int/pdfs/vet/mrls/055499en.pdf Accessed June 10, 2005.

Fairchild, A. s.; Grimes, J.L.; Jones, F.T.; ineland, M. J.; Edens, F.w.; and Sefton, A. E. (2001). Effects of hen age, Bio-Mos, and Flavomycin on poult succeptibility to oral Eschrichia coli challenge. Poult. Sci., 80: 562-571.

Ghosh, H.K.; Halder, G.; Samanta, G.; Paul, S.K.; and Pyne, S.K. (2007). Effect of dietary supplementation of organic acid and mannanoligosaccharide on the performance and gut health of Japanese quail (Coturnix= Coturnix Japaonica). Asian J. poult. Sci., 1: 1-7.

Griggs, J.P. and Jacop, J.P. (2005). Alternatives to antibiotics for organic poultry production. J. Apple. Poult. Res., 14: 750-756.

Guerrero, M. R. (1995). Using yeast culture and lactic acid bacteria in broiler breeder diets. PP 371-378 in Biotechnology in the Feed Industry. T. P. Lyons and K. A. Jacquese, ed. Nottingham University Press, Nottingham

Herzig, I.; Hampl, J.; Docekalove, H.; Pisarikova, B. and Vlcek, J.V. (1994). The effect of sodium huminate on cadmium deposition in the organs of chickens. Vet. Med. (Praha) 39: 175-185.

http/www.fulvic.de/049/animalfeeds/products/huminfeed.html.

http/www.fulvic.de/049/ani-malfeeds/produts/huminfeed.html.

Humin Tech. (2004). Huminfeed - Tierfutterzusatze and laub, R., 1998. Acute systemic toxicity studies of Veternar Medizin and and Huminsaure Basierende Produkte. HuminTeck ${ }^{\circledR}$ HuminTeck $\mathrm{GmbH}$, Heerdter Landstr.189/D, D-40549 Dusseldrof, Germany.

Joone, G.K.; Dekker, J.; and Vanrensburg, C. E. (2003). Investigation of the immunostimulatory properties of oxihumate. Zeitschrift für Naturforschung. J. Biosci, 58: 263-267.

Kocabagli, N.; Alp, M.; Acar, N, and Kahraman, R. (2002). The effects of dietary humate supplementation on broiler growth and carcass yield. Apoult.Sci., 81: 227-230.

Kucukersan; S.; kucukersan, K,; Colpa, I; Goncuoglu, E.; reisli, Z.; and tesilbag, D. (2005). The effects of humic acid on egg production and egg traits of laying hen. Vet. Med. Cech. 50: 40 6-410.

Loddi, M. M.; Nakaghi, I. S. O.; Edens, F.; Tucci, F. M.; Hannas, M. I.; Moraes, V. M. B. and Ariki, J. A. (2002). Effect of mannanoligosaccharides and organic acids on intestinal morphology integrity of broiler evaluated by scanning electron microscope. Proceeding of $11^{\text {th }}$ European Poultry Science Conference, Bremen, Germany, PP: 121. 
Oliveria, M. C.; Gravena, R. A.; Marques R. H..; Cancherini, L. C.; and Rodrigues, E. A. (2006). Morphometry of intestinal mucosa in 21 dayold broiler chickens fed mannanloigosaccharides and blend of enzyme. Poultry Science Assiciation 95 ${ }^{\text {th }}$ Annual Meeting Abstract, July 16-19, 2006.

Oyofo, B. A.; Deloach, J. R.; Corrier, D. E.; Norman, J.O.; Ziprin, R.I. and Mollenhauer, H. H. (1989). Preventation of salmonella typhimurium colonization of broiler with D-mannose. Poult. Sci., 68: 1357-1360.

Patterson, J.A. and K.M. Burkholder, (2003). Application of Prebiotics and Probiotics in poultry production. Poult. Sci., 82: 627-631.

Pukhova, G.G.; Druzhina, N.A.; Stepchenko, L.M.; and Chebotarev, E.E. (1987). Effect of sodium humate on animals irradiated with lethal doses. Radiobiologiia 27: 650-653.

Raju, M.V.I.N. and Devegowda, G. (2002). Esterifed-Glucu-mannan in broiler chickens diets-contaminated with aflatoxin, ochratoxin and t-toxin: Evaluation of its binding ability (invitro) and efficacy as immunomodulator. Asian -Aust. J. Ani, sci., 15: 1051-1056.

Sehermer, C. L.; Maciorowski, K. G.; Bailey, C. A.; Byers, F. M.; and Ricke, S. (1998). Caecal metabolites and microbial populations in chickens consuming diets containing a mined humate compound. J. Sci. Food Agri. 77: 479-486.

Shashidhara, R.G. and Devegowda, G. (2003). Effect of dietary mannanoligosaccharide on broiler breeder production traits and immunity. Poult. Sci., 82: 13-19.

Shin, Y. W., J. G. Kim, and K. Y. Whang. (2005). Effect of supplemental mixed yeast culture and antibiotics on growth performance of weaned pigs. J. Anim. Sci. 83(Suppl. 1):34. (Abstr.)

Spring, P., wenk, C.; Dawson, K.A. and Newman, K.E. (2000). The effects of dietary mannanoligosaccharides on cecal parameters and the concentrations of enteric bacteria in caca of salmonella challenged broiler chicks. Poult. Sci., 79: 205-211.

SPSS (1999). Statistical software package for the social sciences SPSS, Int., USA.

Stackhouse, R.A; and Benson, W.H. (1989). The effect of humic acid on the toxicity and bioavailability of trivalent chromium. Ecotoxical. Environ. Safety 17: 105-111.

Stanley, V. G.; Brown, C,; and Sefton, T. (2000). Single and combined effect of dietary protease and mannanoligosaccharide on the performance of laying hens. Poult. Sci.; 79(Suppl.1): 26.(Abs.).

Talay, U.; Bilgic, M. and Spring, , P. (2004). Effect of mannanoligosaccharides on broiler performance under field condition in Turkey. Procceding of the XXII World's Poultry Congress, Istanbul, $8^{\text {th }}$ to $13^{\text {th }}$ June.

Wang, Q.; Kim, H.J.; Cho, J.H. (2007). Effects of supplemental humic substance on egg production and quality in laying hens. Poult. Sci., 86: 519.

Well ,R.j. (1968). The measurement of certain egg quality : a study of the hens egg : Ed. By T.C. Carter Pub. Oliver and Boy Edinbrugh pp.22226 and 235-236.

Yasar, S.; Gokcimen,A,; Altunas, I,; Yonden, Z. and Petekkaya, E. (2002). Performance and ideal histomorphology of rats treated with humic acid preparations. J.Anim..Nutr. 86: 257-264. 
Yeo, J.; Kim, K. (1997). Effect of feeding diets containing an antibiotic, a probiotic, or yuuca extract on growth and intestinal urease activity in broiler chickens. Poult. Sci. 76: 381-385.

Yoruk, M.A.; Gul, M..; Hayirli, A.and Macit, M. (2004). The effects of supplementation of humate and probiotic on egg production and quality parameters during the late laying period in hens. Poult. Sci., 83: 84-88.

Zhigang, A.; Kocher, A.; Tucker, L. A.; and Choct, M. (2004). The use of oligosaccharides to improve broiler performance. Proceeding of the XXII World's Poultry Congress, Istanbul, $8^{\text {th }}$ to $13^{\text {th }}$ June.

Zhorina, L.V. and Stepchenko, L.M. (1991). The content of free amino acids in the tissues of broiler chicks administered sodium humate in the ration. Biol. Nauk; 10: 147-150.

$$
\begin{aligned}
& \text { تأثير إضافة حمض الهيومك و البيوموس على إنتاج البيض وصفات جودة البيض } \\
& \text { في الاجاج المحلي } \\
& \text { السمرة حسن أبو عجلة*, فوزي صديق عبد الفتاح اسماعيل*, فوزي علي عبد الفني** و }
\end{aligned}
$$

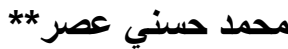

$$
\begin{aligned}
& \text { * ق قدم انتاج الدواجن- كلية الزراعةـ جامعة المنصورة. }
\end{aligned}
$$

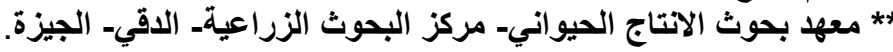

صمدت هذه الدراسة لبحث اضافة حمض الهيو ميك و المنان اوليجو سكريد في علف البياض

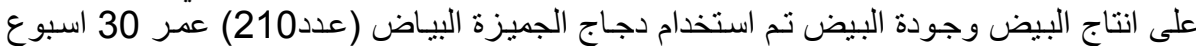

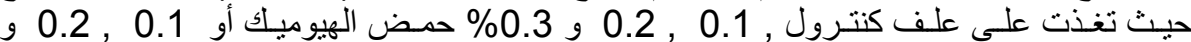

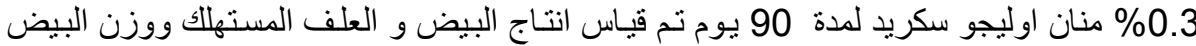

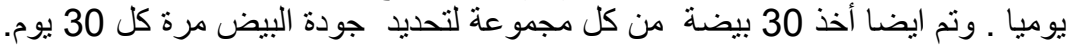

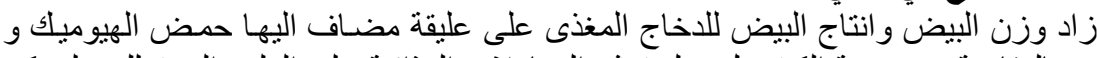

$$
\text { يمكن تلخيص النتائج في الآتي : }
$$

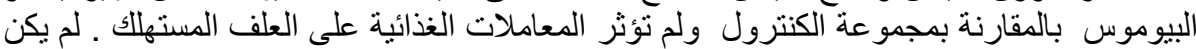

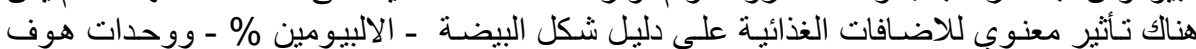

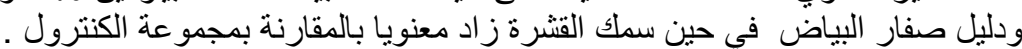

الخلاصة : أن اضافة الهيوميك و البيوموس خلال فترة الانتاج يزيد انتاج البيض ووزن البيض

كلية الزراعة - جامعة المنصورة

كلية الزراعة - جامعة - جامعة الاسكندرية
قام بتحكيم البحث

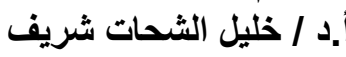

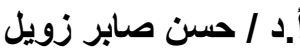

